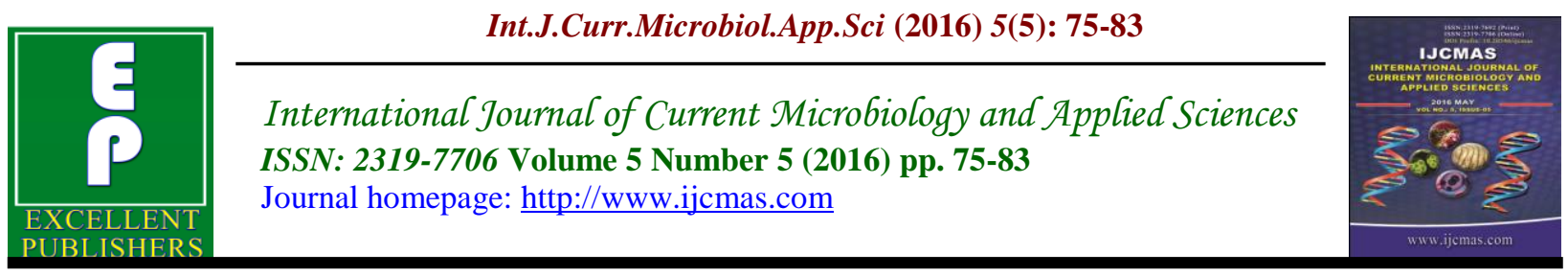

Original Research Article

http://dx.doi.org/10.20546/ijcmas.2016.505.008

\title{
Synthesis of Some Sulfa Drug Derivatives as Antibacterial Agents
}

\author{
Salman A. Ali ${ }^{1}$, Anmar H. Jabbir ${ }^{1 *}$ and Rana A. Mohsie ${ }^{2}$ \\ ${ }^{1}$ Department of Chemistry, Faculty of Science, Al-Nahrain University, Baghdad, Iraq \\ ${ }^{2}$ College of Applied Biotechnology, Al-Nahrain University, Baghdad, Iraq \\ *Corresponding author
}

\begin{tabular}{|c|c|}
\hline & A B S T R A C T \\
\hline Keywords & \multirow{4}{*}{$\begin{array}{l}\text { Sulfa drugs are an important class of synthetic bacteriostatic antibiotics still used } \\
\text { today for the treatment of bacterial infections and those caused by other } \\
\text { microorganisms, sulfa drugs achieve this bacteriostatic action by inhibiting the } \\
\text { synthesis of folic acid in bacteria. The current study has the aim of Synthesis of } \\
\text { some of sulfa drug compounds and Study the biological activity of the synthesized } \\
\text { compounds against two types of bacteria: Staphylococcus aureus (Gram positive) } \\
\text { and Pseudomonas aeruginosa (Gram negative). These compounds were formed } \\
\text { successfully by chlorosulfonation of acetanilide and the product was treated with } \\
\text { different amines and finally amide hydrolysis was necessary to get agents that were } \\
\text { analyzed for IR, UV and melting points. At last, we studied their antibacterial } \\
\text { activity on certain types of bacteria. We carried out an antibacterial evaluation in } \\
\text { vitro of a series of five synthetic sulfa drugs (IIIa, IIIb, IIIc, IIId and IIIe) and from } \\
\text { the results, antibacterial activity studies indicate that halo substituted sulfonamide } \\
\text { (compound IIIc) was more active than the other members. }\end{array}$} \\
\hline $\begin{array}{l}\text { Sulfa drugs, } \\
\text { Staphylococcus } \\
\text { aureus, } \\
\text { Pseudomonas } \\
\text { aeruginosa, } \\
\text { chlorosulfonation, } \\
\text { IR, UV. }\end{array}$ & \\
\hline Article Info & \\
\hline $\begin{array}{l}\text { Accepted: } \\
06 \text { April } 2016 \\
\text { Available Online: } \\
10 \text { May } 2016\end{array}$ & \\
\hline
\end{tabular}

\section{Introduction}

Sulfonamides are an important class of synthetic bacteriostatic antibiotics still used today for the treatment of bacterial infections and those caused by other microorganisms. They are also known as sulfa drugs and were the main source of therapy against bacterial infections before the introduction of penicillin in 1941. Although sulfonamides have for the most part been replaced by other agents, they still maintain considerable action in certain types of infection, for example in the urinary tract, eye and ear, and bronchitis (Mok, 2008). The activity of the sulfa drugs has been extensively studied and can be explained in the following manner. Sulfonamides are typically administered in doses that are bacteriostatic, meaning they prevent or limit bacterial multiplication.

Sulfonamides achieve this bacteriostatic action by inhibiting the synthesis of folic acid in bacteria. Bacteria synthesize their own folic acid using endogenous compounds and enzymes, Endogenous compounds are those that occur naturally in the biological system, Specifically, sulfonamides inhibit the enzyme dihydropteroatesynthetase, an enzyme that catalyzes the conversion of p- 
aminobenzoic acid (PABA) and dihydropteroate diphosphate to dihydropteroic acid, a precursor to folic acid and DNA. Sulfonamides compete with PABA for the "active site" in the dihydropteroatesynthtase enzyme, and are considered to be "competitive inhibitors" of this enzyme. The structural similarity of the sulfonamides to PABA "tricks" the enzyme into binding with the drug (sulfonamide) instead of the endogenous compound (PABA). The displacement of the PABA by the sulfonamide leads to the formation of a "false" metabolite in the folic acid synthesis, which cannot continue through the synthetic sequence (Garcia et al., 2009).

Sulfonamides can be classified into three major groups: oral absorbable agents, oral non absorbable agents and topical. Oral absorbable agents may be further classified as short, medium, or long acting sulfonamides. Sulfonamides are absorbed from the stomach and small intestine and widely distributed to tissues. Sulfonamides and inactivated metabolites are excreted by the kidney mainly through glomerular filtration (Abraham, 2003).

The toxic effects which may arise during sulfonamide therapy are: crystalluria, acute hemolytic anemia, agranulocytosis, a plasticanemia, hypersensitivity reactions, gastrointestinal upsets including anorexia, nausea and vomiting, headache, dizziness, mental depression, and other signs of central nervous system involvement. Hepatitis is a rare but potentially dangerous complication of sulfonamide therapy (Golzar, 2005).

\section{Materials and Methods}

\section{Chemical}

The steps of synthesizing these compounds represented the classical method (scheme 1) which includes reaction of acetanilide $(2.5 \mathrm{~g}$. 0.018 moles) with chlorosulfonic acid $(6.25 \mathrm{ml}, \quad 0.093$ moles $)$ in $250 \mathrm{ml}$ conical flask on an ice-bath. When the addition has been made, under stirring, heat the reaction mixture on a water bath (5060C) for 1 hour in order to complete the reaction. Allow the flask to cool to room temperature and slowly pour the contents, with vigorous stirring, into a beaker containing 100g. Of crushed ice, a milkywhite precipitate is formed. This suspension was filtered off, washed with a little cold water and air dried to give crude product (Vogel, 1956).

To crude product dissolved in diethyl ether $(30 \mathrm{ml})$ was added dropwise o-methyl aniline ( $2.5 \mathrm{ml}, 0.023 \mathrm{moles})$. Under stirring it took one hour for the reaction to complete. After the completion of the reaction, the precipitate was collected by filtration and air dried. The same procedure was repeated with 0.023 moles of each amine $(2.56 \mathrm{ml} \mathrm{o}-$ methoxy aniline, $2.93 \mathrm{~g}$ p-chloro aniline, $2.26 \mathrm{ml}$ Piperidine, $2 \mathrm{ml}$ morpholine) (Hadizadeh et al., 2007).

The product from the previous step is placed in a $50 \mathrm{~mL}$ round-bottom flask equipped with a magnetic stir bar. Dilute hydrochloric acid (5 $\mathrm{ml}$ of conc. $\mathrm{HCl}$ in $10 \mathrm{ml}$ of water) is added to the flask. The flask is fitted with a condenser and heated at reflux with constant stirring for (30-45) minutes, after which it is allowed to cool to room temperature. After cooling, the reaction mixture is neutralized by slow addition of a 10\% NaHCO3 solution with stirring until it tests slightly alkaline to $\mathrm{pH}$ paper. A precipitate may have begun to form during neutralization. Cool the beaker in an ice bath to complete the precipitation of product. It may be necessary to gently scratch the inside bottom of the beaker to induce crystallization. The product is collected by filtration, washed with a 
small amount of ice cold water and air dried. The same procedure was repeated with each compounds (Vogel, 1956; Pvia and Lampman, 2011).

All the starting materials and reagents were obtained from commercial sources and were used without further purification. Acetanilide was supplied by Merck, Chlorosulfonic acid was from Fluka and the other chemicals were procured by $\mathrm{BDH}$.

\section{Antimicrobial Activity}

In this study, the synthesized compounds were evaluated for their in vitro antimicrobial activity against the pathogenic bacteria, two bacterial species were used: one of them gram positive bacteria which was Staphylococcus aureus, the other gram negative bacteria which was pseudomonas aeruginosa. Well diffusion method was used to determine the inhibiting power of the prepared compounds against the pathogenic bacteria (Moumitaand Thankamani, 2013). Sulfamethoxazole was used to compare the power of inhibition.

This method depends upon the variation in concentration of the prepared compounds. A series of concentrations were made from the already prepared compounds with the range from $(50,25,12,6$, and $3 \mathrm{mg} / \mathrm{ml})$. Sulfamethoxazole was used as a reference antibiotic drugs and DMSO was used as a solvent for these compounds.

\section{Antibacterial Evaluation}

Medium Inoculated bacteria suspension were diluted by $1 / 100$ by using normalsaline solution with concentration of $(0.85 \%)$ to prevent crowded growth. (0.1 $\mathrm{mL}$ ) of bacteria diluted suspension was transported to each plate and spread by using sterilized cotton spreader on test medium surface. The Plates were left for (15-20) min. at $37^{\circ} \mathrm{C}$ to make absorption. The plates of Mueller Hinton agar were inoculated by S.aureus and P.aeruginosa. In each medium six pores were made by the use of a sterile dry rod with a diameter of 5 $\mathrm{mm}$, these pores were made with equal distance between each other, then the solutions of different concentrations of the prepared compounds were added using fixed amount of $0.1 \mathrm{~mL}$ from each concentration in one pore and DMSO as control, to see the effect of solvent for each type of bacteria. These plates were incubated at $37 \mathrm{C}^{0}$ for 24 hrs. After the incubation, the inhibition zone was measured for each pore using a ruler in amillimeter $(\mathrm{mm})$. The zone of inhibition is defined as the translucent area which surrounds the disc including the diameter of the disc that lacks bacterial growth. The bacteria was considered sensitive, meansensitive or resistant depending on inhibition zone.

\section{Results and Discussion}

\section{Chemistry}

Acetanilide was choosen as a starting material based on its amino group which is already protected by acetyl and later on can be deprotected to get the free amino group again for further synthesis when the desired sulfa compounds could obtained. Acetanilide was converted to its corresponding sulfonyl chloride by chlorosulfonation by the direct reaction of chlorosulfonic acid with it ${ }^{(56)}$. The suggested amino compounds for preparation of sulfa derivatives are verified the from aromatic with either activated and deactivated group or aliphatic residue like piperidine and morpholine. These products were prepared by the condensation of precursor (I) with the amines, i.e., (2-methylaniline, 2methoxyaniline, 4-chloroaniline, morpholine 
and piperdine) to furnish the 4-acetamido- $\mathrm{N}$ substituted benzenesulfonamides (IIa, IIb, IIc, IId and IIe) respectively. The acetyl group was removed to afford the4-amino-Nsubstituted benzenesulfonamides (IIIa, IIIb, IIIc, IIId and IIIe). The synthesis routes of the compounds (IIIa, IIIb, IIIc, IIId and IIIe) are shown in scheme.1.

The percent yield, physical description and the corresponding melting point of any compound are shown in table1. Infrared identification was done by $\mathrm{KBr}$ disc aiming the proof of their formation, functional groups and structures and the bands are listed on table2. Ultraviolet spectroscopy was applied on DMSO solutions and the related $\lambda$ maxs were appeared as per table.3.

\section{Antibacterial Activity}

Pathogenic microorganisms cause different kinds of diseases to human and animals. Discovery of chemotherapeutic agents played a very important role in controlling and preventing such diseases. Chemotherapeutic agents are isolated either from living organisms known as antibiotics like penicillin and tetracycline etc., or they are chemical compounds prepared by chemists such as sulfa drugs. Microorganisms have the ability to develop resistance to these chemotherapeutic agents and such strains which are resistant causing major problem in treatment of microbial infections. For this reason searching for new antimicrobial agents is continuous process and great efforts have been employed to find new antibiotics or new compounds with good antimicrobial activity which might be suitable to be used as chemotherapeutic agents (Endimiani et al., 2005).

The prepared compounds (IIIa and IIIb) had no inhibiting action on growth of the used germs and, therefore, these compounds possessed no antibacterial activity against the previously mentioned types of gram positive and gram negative bacteria with all concentrations (resistance).The most interesting results were with compound (IIIc) which showed the best antibacterial activity on staphylococcus aureus with inhibition zones $17 \mathrm{~mm}, 14 \mathrm{~mm}$ and $8 \mathrm{~mm}$ at concentrations (50, 25 and $12 \mathrm{mg} / \mathrm{ml})$ respectively. On pseudomonas aeruginosa, the compound (IIIc) showed one inhibition zone $13 \mathrm{~mm}$ at $(50 \mathrm{mg} / \mathrm{ml})$. The compound (IIId) showed two inhibition zones $16 \mathrm{~mm}$ and $10 \mathrm{~mm}$ at $(50,25 \mathrm{mg} / \mathrm{ml})$ respectively on staphylococcus aureus, while compound (IIId) showed one inhibition zone $16 \mathrm{~mm}$ at (50) $\mathrm{mg} / \mathrm{ml}$ on pseudomonas aeruginosa. The compound (IIIe) have inhibition ability $9 \mathrm{~mm}$ at $(50) \mathrm{mg} / \mathrm{ml}$ on staphylococcus aureus, while on pseudomonas aeruginosa the inhibition zone was not observed (resistance) (Badampudi et al., 2014).

The inhibition zones caused by the various compounds on the staphylococcus aureus and pseudomonas aeruginosa were examined and the results were listed in table 4 and table 5 respectively.

Table.1 Physical Properties of Synthesized Compounds

\begin{tabular}{|c|c|c|c|c|c|}
\hline Compounds & Colour & M.P. $\left({ }^{\circ} \mathbf{C}\right)$ & Yield (\%) & M. Wt. & Formula \\
\hline IIIa & White & $185-187$ & 86 & 262.33 & $\mathrm{C}_{13} \mathrm{H}_{14} \mathrm{~N}_{2} \mathrm{SO}_{2}$ \\
\hline IIIb & Pale White & $204-206$ & 80 & 278.33 & $\mathrm{C}_{13} \mathrm{H}_{14} \mathrm{~N}_{2} \mathrm{SO}_{3}$ \\
\hline IIIc & Yellowish white & $196-198$ & 52 & 282.75 & $\mathrm{C}_{12} \mathrm{H}_{11} \mathrm{~N}_{2} \mathrm{SO}_{2} \mathrm{Cl}$ \\
\hline IIId & White & $174-176$ & 76 & 242.29 & $\mathrm{C}_{10} \mathrm{H}_{14} \mathrm{~N}_{2} \mathrm{SO}_{3}$ \\
\hline IIIe & White & $160-162$ & 78 & 240.32 & $\mathrm{C}_{11} \mathrm{H}_{16} \mathrm{~N}_{2} \mathrm{SO}_{2}$ \\
\hline
\end{tabular}


Table.2 Infrared Spectra of the Prepared Compounds

\begin{tabular}{|c|l|}
\hline Compounds & Vibration bands $\mathrm{Cm}^{-1}$ \\
\hline IIIa & $\mathrm{SO}_{2}=1315,1149$ \\
& $\mathrm{NH}_{2}=3444,3423$ \\
& $\mathrm{CH}_{3}=2902,2864$ Stretching \\
& $\mathrm{CH}_{3}=1465,1398$ bending \\
\hline IIIb & $\mathrm{SO}_{2}=1323,1157$ \\
& $\mathrm{NH}_{2}=3367,3313$ \\
& $\mathrm{O}_{-} \mathrm{CH}_{3}=1111$ \\
\hline IIIc & $\mathrm{SO}_{2}=1323,1157$ \\
& $\mathrm{NH}_{2}=3383,3228$ \\
& $\mathrm{C}-\mathrm{Cl}=640$ \\
\hline IIId & $\mathrm{SO}_{2}=1315,1165$ \\
& $\mathrm{NH}_{2}=3309,3263$ \\
& $\mathrm{C}-\mathrm{O}=1053$ \\
\hline IIIe & $\mathrm{SO}_{2}=1323,1161$ \\
& $\mathrm{NH}_{2}=3294,3259$ \\
& $\mathrm{CH}_{2}=2927,2854$ Stretching \\
\hline
\end{tabular}

Table.3 Electronic Spectra of the Prepared Compounds

\begin{tabular}{|c|c|c|}
\hline Comps. & $\begin{array}{c}\text { Absorption } \\
\text { Bands(nm) }\end{array}$ & Assignment \\
\hline \multirow{3}{*}{ IIIa } & 208 & $\pi-\pi^{*}$ \\
& 233 & $\pi-\pi^{*}$ \\
& 263 & $\mathrm{n}-\pi^{*}$ \\
\hline \multirow{3}{*}{ IIIb } & 208 & $\pi-\pi^{*}$ \\
& 231 & $\pi-\pi^{*}$ \\
& 266 & $\mathrm{n}-\pi^{*}$ \\
\hline \multirow{3}{*}{ IIIc } & 210 & $\pi-\pi^{*}$ \\
& 237 & $\pi-\pi^{*}$ \\
\hline \multirow{2}{*}{ IIId } & 265 & $\mathrm{n}-\pi^{*}$ \\
\hline \multirow{2}{*}{ IIIe } & 208 & $\pi-\pi^{*}$ \\
& 260 & $\pi-\pi^{*}$ \\
& 283 & $\mathrm{n}-\pi^{*}$ \\
\hline
\end{tabular}


Table.4 The Inhibition Zones in MM of Synthesized Compounds against Staphylococcus aureus

\begin{tabular}{|c|c|c|}
\hline Compounds & Concentrations $\mathrm{mg} / \mathrm{ml}$ & Inhibition Zones in $\mathrm{mm}$ \\
\hline \multirow{5}{*}{ IIIa } & 50 & No Inhibition \\
\hline & 25 & Same \\
\hline & 12 & Same \\
\hline & 6 & Same \\
\hline & 3 & Same \\
\hline \multirow{5}{*}{ IIIb } & 50 & No Inhibition \\
\hline & 25 & Same \\
\hline & 12 & Same \\
\hline & 6 & Same \\
\hline & 3 & Same \\
\hline \multirow{5}{*}{ IIIC } & 50 & 17 \\
\hline & 25 & 14 \\
\hline & 12 & 8 \\
\hline & 6 & No Inhibition \\
\hline & 3 & No Inhibition \\
\hline \multirow{5}{*}{ IIId } & 50 & 16 \\
\hline & 25 & 10 \\
\hline & 12 & No Inhibition \\
\hline & 6 & No Inhibition \\
\hline & 3 & No Inhibition \\
\hline \multirow{5}{*}{ IIIe } & 50 & 10 \\
\hline & 25 & No Inhibition \\
\hline & 12 & No Inhibition \\
\hline & 6 & No Inhibition \\
\hline & 3 & No Inhibition \\
\hline \multirow{5}{*}{$\begin{array}{l}\text { Sulfamethoxazole } \\
\text { as Antibiotic } \\
\text { Control }\end{array}$} & 50 & Synergistic \\
\hline & 25 & Same \\
\hline & 12 & Same \\
\hline & 6 & Same \\
\hline & 3 & Same \\
\hline $\begin{array}{c}\text { DMSO } \\
\text { as Solvent }\end{array}$ & - & No Inhibition \\
\hline
\end{tabular}


Table.5 The Inhibition Zones in MM of Synthesized Compounds against Pseudomonas aeruginosa

\begin{tabular}{|c|c|c|}
\hline Compounds & $\begin{array}{c}\text { Concentrations } \\
\mathrm{mg} / \mathrm{ml}\end{array}$ & Inhibition Zones in $\mathbf{~ m m}$ \\
\hline \multirow{5}{*}{ IIIa } & 50 & No Inhibition \\
\hline & 25 & Same \\
\hline & 12 & Same \\
\hline & 6 & Same \\
\hline & 3 & Same \\
\hline \multirow{5}{*}{ IIIb } & 50 & No Inhibition \\
\hline & 25 & Same \\
\hline & 12 & Same \\
\hline & 6 & Same \\
\hline & 3 & Same \\
\hline \multirow{5}{*}{ IIIc } & 50 & 13 \\
\hline & 25 & No Inhibition \\
\hline & 12 & No Inhibition \\
\hline & 6 & No Inhibition \\
\hline & 3 & No Inhibition \\
\hline \multirow{5}{*}{ IIId } & 50 & 16 \\
\hline & 25 & No Inhibition \\
\hline & 12 & No Inhibition \\
\hline & 6 & No Inhibition \\
\hline & 3 & No Inhibition \\
\hline \multirow{5}{*}{ IIIe } & 50 & No Inhibition \\
\hline & 25 & Same \\
\hline & 12 & Same \\
\hline & 6 & Same \\
\hline & 3 & Same \\
\hline \multirow{5}{*}{$\begin{array}{l}\text { Sulfamethoxazole as } \\
\text { Antibiotic Control }\end{array}$} & 50 & Synergistic \\
\hline & 25 & Same \\
\hline & 12 & Same \\
\hline & 6 & Same \\
\hline & 3 & Same \\
\hline $\begin{array}{c}\text { DMSO } \\
\text { as Solvent }\end{array}$ & ----- & No Inhibition \\
\hline
\end{tabular}


Scheme.1 The Chemical Steps of the Synthesized Compounds
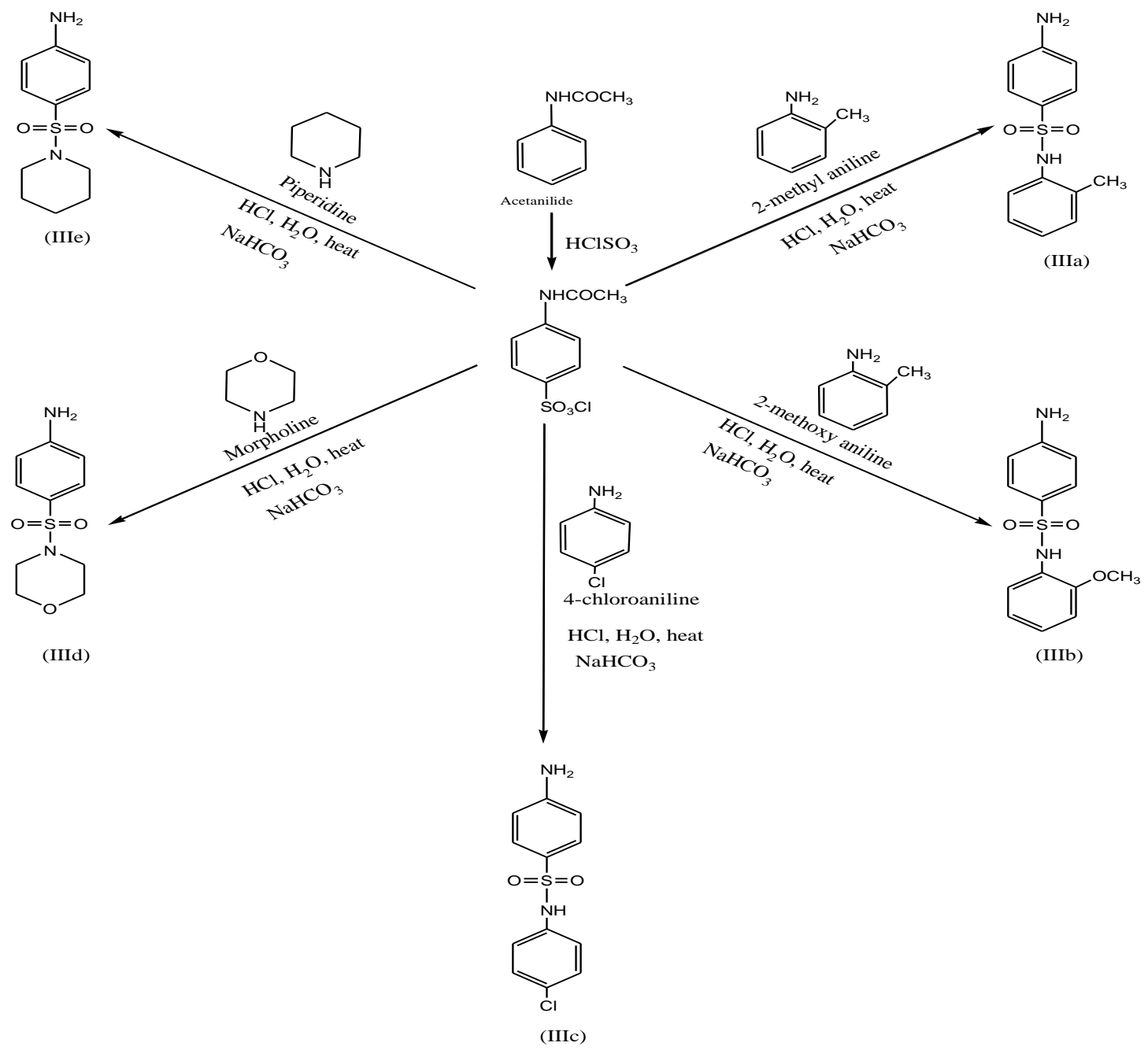

In conclusion, for this study, we carried out an antibacterial evaluation in vitro of a series of five synthetic sulfonamides (IIIa, IIIb, IIIc, IIId and IIIe), against gram positive and gram negative clinical strains isolated from patients presenting burns infections: Staphylococcus aureus and Pseudomonas aeruginosa. From the results, antibacterial activity studies indicate that halo substituted sulfonamide (compound IIIc) was more active than the other members (IIIa, IIIb, IIId and IIIe). The prepared compounds (IIIc, IIId and IIIe) showed inhibition activity as antibacterial agents less than sulfamethoxazole (the reference drug showed better biological activity than our compounds in all tested strains "synergistic effect" against Staphylococcus aureus and Pseudomonas aeruginosa).

\section{References}

Abraham, D. 2003. Burgers Medicinal Chemistry And Drug Discovery, John Wiley And Sons, Hoboken.

Badampudi, S., Aluru, R., Papammagari, R., Rao, R. 2014. Synthesis, Characterization And Pharmacological Evaluation Of Certain Sulfonamide Containing Hetrocyclic Motifs, J. Pol. Ann. 
Med., 21(2): 75-81.

Endimiani, A., Luzzaro, F., Brigante, G. 2005. Proteus Mirabilis Bloodstream Infections: Risk Factors And Treatment Outcome Related To The Expression Of Extended-Spectrum Beta-Lactamases, J. Antimicrob. Agents Chemother., 49(7): 25982605.

Garcia, M., Diaz, S., Barcelo, D. 2009. Combining chemical analysis and ecotoxicity to determine environmental exposure and to assess risk from sulfonamids, $T r$. Anal. chem., 75: 417-434.

Golzar, G. 2005. Synthesis and Structural studies of metal complexes of Sulfa drugs, PH.D. Thesis, Department of chemistry, Cardiff university.

Hadizadeh, F., Moradi, A., Naghibi, G., Vojdani, M., Behravan, J.,
Ramezani, M. 2007. Synthesis And Antitumor Activity of Substituted Succinamides Using a Potato Disc Tumor Induction Assay, Int. J. Biomed. Sci., 60-64.

Mok, B. 2008. The synthesis of functionalized Sulfonamides, PH.D. Thesis, Chemistry Department, university college London.

Moumita, B., Thankamani, V. 2013. Antimicrobial Activity of Plant Mukia Maderasatana, Int. J. Pharm. Sci., 5(4): 199-202.

Pvia, D., Lampman, G. 2011. A Small Scale Approach to Organic Laboratory Techniques, $3^{\text {rd }}$ ED., Cengage Learning.

Vogel, A. 1956. Text book of Practical Organic Chemistry, ${ }^{\text {rd }}$ ED., Longman Group, London.

\section{How to cite this article:}

Salman A. Ali, Anmar H. Jabbir and Rana A. Mohsie. 2016. Synthesis of Some Sulfa Drug Derivatives as Antibacterial Agents. Int.J.Curr.Microbiol.App.Sci. 5(5): 75-83. doi: http://dx.doi.org/10.20546/ijcmas.2016.505.008 